\title{
ЗАСОБИ ТОРГОВЕЛЬНОГО ЗАХИСТУ ЯК ІНСТРУМЕНТ РОЗВИТКУ КОНКУРЕНЦIї У РЕГІОНАЛЬНИХ ТОРГОВЕЛЬНИХ УГОДАХ
}

\author{
ГЛАДШТЕЙН АнНа Леонідівна - викладач кафедри міжнародного \\ приватного права Інституту міжнародних відносин Київського національного \\ університету імені Тараса Шевченка \\ ORCID: 0000000170062678 \\ УДК 341.9.01 \\ DOI 10.32782/EP.2021.29
}

Статья посвящена регулированию средств торговой защить на уровне региональньлх торговьих соглашений. Автор приходит к вълводу, что характерньлми чертами средств торговой зашить можно считать общие начала их процедурной реализащии (речь идет прежде всего о необходимости проведения соответствующего расследования как основания для применения каждого из средств торговой зашитьи). Констатируется, что средства торговой защитьл имеют ряд общих черт с составом правонарушения как основанием юридической ответственности (как институтом зашить прав, свобод и интересов субъектов права в начиональной правовой доктрине). Речь идет о необходимости установления таких юридически значимьхх обстоятельств, как осуществление запрещенньхх действий (демпинг; запрещенное субсидирование); наличие вреда; причинно-следственная связь между вредом и последствиями, повлекшими соответствующие действия (демпинг либо запрещенное субсидирование). В статье детально раскрылть основнъле начала концепиии национального товаропроизводителя как субгекта, на защиту которого направленъ средства торговой защить как институт конкурентного права.

Ключевъге слова: средства торговой зашитьл, зашита конкуренции, региональньие торговъие соглашения, антидемпинг, субсидии, средства заuзить

Постановка проблеми

Одним 3 інститутів конкурентного права у регіональних торговельних угодах (далі- РТУ) є засоби торговельного захисту.
У спеціальній літературі зазначається, що засоби торговельного захисту є складовою торговельної політики, що властива багатьом країнам (як розвиненим, так і тим, що розвиваються). Метою застосування засобів торговельного захисту є захист внутрішніх ринків від іноземної конкуренції [1, С. 1].

До засобів торговельного захисту, як правило, відносять антидемпінгові заходи, антисубсидійні заходи та заходи захисту.

Зауважимо, що термінологія у конкретних РТУ може бути різною з огляду на особливості нормотворчої техніки або правові традиції конкретних держав. Водночас можна стверджувати про відносну усталеність доктринальних підходів до визначення складових політики щодо засобів торговельного захисту.

Подекуди такі засоби об'єктивуються в окремій статті (главі, розділі). Йдеться, наприклад, про РТУ Туреччина-Сінгапур [2]; РТУ Гонконг-Грузія [3].

Водночас таку легітимацію засобів торговельного захисту не можна визначити загальною тенденцією, адже подекуди РТУ врегульовують окремі види засобів торговельного захисту в межах інших структурних підрозділів. Так, РТУ ЕС-Південна Корея [4] регулює субсидії у межах загального розділу, присвяченого конкуренції.

Відсутність єдиної концепції легітимації засобів торговельного захисту в РТУ зумовлюють актуальність теми цього дослідження. 
Аналіз останніх досліджень і публікацій

Засоби торговельного захисту досліджувалися у правовій доктрині доволі фрагментарно. Переважно йдеться про зарубіжну правову доктрину. Серед розробок зарубіжних вчених слід виокремити дослідження Ж.-Ф. Беллі та П. Бере [1]; Дж. Чако, Й. Юмен та Х. Міранди [5]; П. ван ден Боске та В. Здоуча [6]. Окремі ознаки антидемпінгу розглядались Т. Г. Камініною [7].

Метою статті є дослідження змісту та основних моделей регулювання засобів торговельного захисту у РТУ, а також визначення місця інституту торговельного захисту 3-поміж інших інститутів конкурентного права у РТУ.

\section{Виклад основного матеріалу}

Загальні засади Европейсъкого підходу до регулювання конкурентних відносин в РТУ встановлені у статтях 131 та 133 Договору про заснування Європейської Спільноти [8].

Наведені норми закладають підгрунтя регулювання інституту засобів торговельного захисту у $\mathrm{EC}$, адже встановлюють необхідність захисту торгівлі, зокрема, шляхом регулювання демпінгу та субсидій.

Розглянемо правові конструкції, що розглядаються у контексті засобів торговельного захисту в РТУ.

Антисубсидійні заходи. Значний інтерес у контексті дослідження регулювання субсидій на рівні РТУ становить Угода про зону вільної торгівлі між $\mathrm{EC}$ та Південною Кореєю [4].

У спеціальній літературі висловлюється думка, що метою закріплення норм щодо регулювання субсидій у наведеній вище Угоді є захист європейських виробників від недобросовісної конкуренції з боку корейських компаній, які отримують значні урядові субсидії, адже основними компаніямиотримувачами субсидій $\epsilon$ великі суднобудівні компанії Південної Кореї.

Відзначимо, що наведена дискусія мала доволі тривалу історію, одним з наслідків якої можна вважати розслідування цього питання, ініційовані EC у межах механізму вирішення спорів СОТ (йдеться про справу «Корея - заходи, що впливають на торгівлю торговими суднами» [9]).

Необхідно зазначити, що правило про можливу протиправність субсидій (у досліджуваному контексті - у вигляді запозичень та гарантій повернення авансових платежів) сформувалось саме за результатами розгляду наведеної вище справи.

Відповідне рішення у березні 2005 року було ухвалено третейською групою, сформованою для розгляду цієї справи. Наведеним рішенням встановлювалось, що окремі 3 таких запозичень та гарантій повернення авансових платежів, що надавались Ексімбанком Південної Кореї, є забороненими експортними субсидіями на підставі статей 3.1 (а) та 3.2 Угоди з субсидій та компенсанційних заходів СОТ. Цим рішенням Південну Корею було зобов'язано скасувати наведені субсидії протягом 90 днів.

Окремо зауважимо, що остаточного компромісу з цього питання між $\mathbf{C C}$ та Південною Кореєю так і не було досягнуто, адже Південна Корея звітувала перед відповідною третейською групою про виконання зобов'язань зі скасування субсидій, з чим не погодився $\mathrm{EC}$.

Наведена ситуація стала підгрунтям для формулювання норм щодо регулювання субсидій в РТУ між СС та Південною Кореєю, які за своїм змістом є заборонними щодо окремих видів субсидій.

У спеціальній літературі також констатується, що таке закріплення антисубсидійних правил у межах РТУ є першим випадком закріплення обмежувальних норм щодо субсидій.

Визначення субсидій надається в Угоді СОТ про субсидії та компенсаційні заходи (стаття 1) [10].

Відзначимо, що пункт 1.2 цитованої норми деталізує, що обов'язковою ознакою субсидії для поширення на неї положень відповідної угоди є її «адресність». Йдеться про спрямованість відповідної субсидії до конкретного учасника відповідних відносин.

Не маючи на меті детального розгляду процедури застосування антисубсидійних заходів, звернемо увагу на деякі положен- 


\section{Міжнародне право}

ня, які становлять інтерес у контексті досягнення мети та завдань даного дослідження.

Йдеться, наприклад, про положення статті 5 цитованої угоди, яка встановлює, що члени СОТ не можуть спричиняти несприятливі наслідки наданням субсидій, наведених у статті 1 цієї угоди.

Відзначимо, що орієнтовний перелік таких несприятливих наслідків встановлений абзацом 2 статті 5 наведеної угоди. Зокрема, йдеться, про: (а) завдання шкоди галузі вітчизняного виробництва іншого члена COT; (b) анулювання або заподіяння шкоди перевагам, що їх прямо чи непрямо здобувають члени СОТ за ГАТТ 1994, зокрема переваг від поступок, встановлених у статті II ГАТТ 1994; (с) завдання серйозної шкоди інтересам інших членів СОТ.

Тобто йдеться про несприятливі наслідки надання субсидій (здебільшого, шкоду), за наявності яких держава зобов'язується понести відповідальність у вигляді вжиття до неї відповідних заходів.

Стаття 9 Угоди СОТ про субсидії та компенсаційні заходи встановлює типове для сучасного регулювання конкурентних відносин зобов'язання щодо надання взаємних консультацій за наявності визначених цією статтею умов.

Зазначимо, що зобов'язання держав щодо взаємного консультування з окремих питань, а також запровадження вимог прозорості, можна вважати тенденцією сучасного регулювання конкурентних відносин на міжнародному рівні.

Цитований вище розділ РТУ СС-Південна Корея також містить положення щодо прозорості (транспарентності), які стосуються надання інформації щодо загальної суми субсидій, їх форм та секторального розподілу.

Сторони цитованої РТУ також зобов'язуються надавати додаткову інформацію по запиту щодо схем субсидіювання та (або) окремих субсидіях.

Вимоги щодо прозорості у сфері засобів торговельного захисту встановлені і в інших РТУ.

Так, глава 3 («засоби торговельного захисту») РТУ Туреччина- Сінгапур [2] встановлюе правила прозорості та обміну інформацією (стаття 3.2) щодо антидемпінгу.
У наведеній статті встановлюється, зокрема, обов'язок сторін письмово повідомляти щодо застосування застереження про антидемпінгові заяви щодо імпорту на ранній стадії антидемпінгового розслідування.

При цьому обидві сторони забезпечують повне та суттєве розкриття усіх значних факторів та мотивів, що покладаються в основу рішення щодо застосування тимчасових заходів до прийняття остаточного рішення.

Розкриття відповідної інформації здійснюється письмово та з урахуванням часу для надання коментарів іншої сторони.

Можна констатувати значну інтегрованість до цитованої РТУ документів у сфері регулювання засобів торговельного захисту СОТ, посилання на які містяться у главі 3 відповідної РТУ.

Йдеться, передусім, про Угоду про застосування статті VI ГАTT [11] (так звана «Антидемпінгова угода СОТ») та Угоду про субсидії та компенсаційні заходи [10], якою врегульовано загальні засади надання субсидій в праві СОТ.

Наведеними угодами визначені основні поняття у сфері антидемпінгу, наданні субсидій та компенсаційних заходів, а також процедура розслідувань у разі наявності відповідних порушень.

Так, стаття 2 Угоди про застосування статті VI ГАTT визначає поняття товару, що є предметом демпінгу, під яким розуміється такий товар, що вводиться в торгівлю іншої країни за ціною, нижчою за його нормальну вартість, якщо експортна ціна товару, що експортується з однієї країни до іншої, є меншою, ніж порівнянна ціна, яка встановлюється у звичайному ході торгівлі на подібний товар, призначений для споживання в країні-експортері.

3 наведеного можна дійти висновку, що під «демпінгом» розуміється штучне заниження ціни товару в межах його реалізації в іншій країні порівняно $з$ його ціною у країні-експортері.

Зазначимо, що СОТ визначає демпінг як ситуацію міжнародної цінової дискримінації, за якої ціна товару при продажі в країні-імпортері інша, ніж ціна цього товару на ринку країни-експортера. Таким чином, у 
найпростіших випадках демпінг можна визначити просто шляхом порівняння цін на двох ринках [детальніше див.: 12].

Отже, йдеться про цінову дискримінацію між національними ринками країн, за якої той самий продукт продається на різних національних ринках за різними цінами без економічного чи комерційного обгрунтування.

Зауважимо, що такі дії найчастіше кваліфікуються як нечесна торговельна практика, за якої виробник, що користується захистом на внутрішньому ринку, і таким чином, може встановлювати високі ціни на своєму ринку, потім штучно занижує ціни на експортних ринках. Найчастіше демпінг означає, що підприємство продає товар на іноземному ринку за ціною нижче тієї, котра превалює на внутрішньому ринку.

Окремо відзначимо, що ГАТТ не забороняє демпінг, який наносить шкоду національному товаровиробнику, а лише засуджує його, що обумовлюється спрямованістю СОТ тільки на регулювання міждержавних відносин i, таким чином, виключає заборону демпінгу приватним суб'єктам [див., наприклад: 13].

Разом 3 тим, ГАТТ дозволяє державамчленам, у яких іноземний товар реалізується за заниженими цінами, вжити захисних заходів, за умови доведення факту, що товар продається за демпінговими цінами та одночасно наносить шкоду національному виробництву аналогічних товарів.

Водночас дискреційні межі державного регулювання демпінгу є доволі широкими, адже країни імпорту товару можуть бути заінтересованими у демпінговому імпорті, оскільки споживачі товару отримають економічні переваги від низьких цін на внутрішньому ринку.

Відповідно до статті 6 ГАТТ сторони визнають, що демпінг, через який товари однієї країни потрапляють на ринок іншої країни за вартістю меншою, ніж нормальна вартість товарів, повинен засуджуватися, якщо він спричиняє матеріальну шкоду чи створює загрозу матеріальної шкоди промисловості, створеній на території країничлена СОТ, чи значно затримує створення вітчизняної промисловості.
Доволі фрагментарний характер визначення демпінгу, який $є$ складним економічним явищем, у статті 2 Угоди про застосування статті VI ГАТТ зумовив значну кількість їі тлумачень.

Зокрема, тлумачення цієї норми здійснювалось у звітах Групи експертів та Апеляційного органу СОТ. Так, у справі Thailand-H-Beams [14] було встановлено, що стаття 2 Угоди про антидемпінг включає комплексні зобов'язання стосовно визначення демпінгу. Таким чином, член COT, який бажає оскаржити результати антидемпінгового розслідування, винесені іншим членом СОТ, повинен досить детально обгрунтувати порушення своїх прав у запиті про утворення Групи експертів.

Відповідно до рішення Апеляційного органу СОТ словосполучення «для цілей цієї Угоди» означає, що стаття 2.1 Угоди про антидемпінг описує умови, в яких товар вважається таким, що демпінгується для иілей всієї Угоди про антидемпінг.

Слід зазначити, що Угода про антидемпінг передбачає можливість накладання антидемпінгового мита у разі завдання демпінгом матеріальної шкоди або створення загрози промисловості на території сторони, що імпортує демпінгові продукти, чи гальмує розвиток вітчизняної промисловосTi.

Відповідно, якщо буде доведено, що імпортовані продукти наносять таку шкоду країні-імпортеру, вона може запровадити антидемпінгові заходи для того, щоб захистити національного товаровиробника, якому завдано шкоду демпінгом, або попередити загрозу такої шкоди.

Обов'язкова наявність шкоди (або загроза ії завдання) дає підстави дійти висновку про спорідненість наведеної юридичної конструкції із складом правопорушення, основним елементом якого, як правило, вважається наявність шкоди [див., наприклад: $15]$.

Таку спорідненість підтверджують і спеціальні дослідження.

Так, відповідно до доповіді ЮНКТАД [16], поняття «шкода» передбачає з'ясування факту завдання демпінговим імпортом негативних майнових наслідків 


\section{Міжнародне право}

національній промисловості, яка виробляє аналогічний товар. По суті, існує чотири взаємопов'язані елементи, які необхідно довести для визначення шкоди: (1) поняття подібного товару для цілей шкоди; (2) поняття національного товаровиробника; (3) поняття майнової шкоди; (4) встановлення причинно-наслідкового зв’язку між демпінговим імпортом, що спричиняе наявність майнової шкоди [17, С. 63-64].

Таким чином, можна дійти висновку, що попри віднесення окремих елементів «демпінгового порушення» у зарубіжній літературі до елементів шкоди йдеться про спеиибічний вид складу правопорушення.

Відтак, на нашу думку, підставою застосування антидемпінгових заходів є склад правопорушення у сфері відносин конкуренції.

Наведені висновки можна 3 певною мірою умовності поширити і на порушення у сфері надання субсидій.

Відзначимо, що подекуди демпінг кваліфікується як один з видів обмежувальної ділової практики [7], а в окремих випадках як недобросовісна конкуренція. Демпінгом вважається також така торговельна практика експортерів, для якої не характерна суттєва різниця відповідних внутрішніх та зовнішніх цін, але іiі наслідки аналогічні «класичному» демпінгу.

У статті 3 Угоди про застосування статті VI ГАТT використовується термін «демпінговий імпорт». Водночас численні справи стосуються демпінгових і не демпінгових трансакцій. Більше того, рішення про демпінг найчастіше приймаються на основі аналізу взаємовідносин виробник-виробник i, таким чином, існує можливість того, що певні виробники не вдавалися до демпінгу.

Отже, концептуальним питанням є можливість визначення не демпінгового імпорту демпінгом при визначенні шкоди.

У справі Індія - постільна білизна [18] Індія заявила, що не демпінгові трансакції не повинні братися до уваги при визначенні шкоди. Комітет 3 антидемпінгової практики не погодився 3 тим, що Угода про застосування статті VI ГАТT передбачає таку особливість. Водночас Апеляційний Орган СОТ у своєму висновку скасував рішення
Комітету і визнав позицію Індії правомірною.

Причинно-наслідковий зв'язок між демпінгом та шкодою також $\epsilon$ надзвичайно важливим елементом при доведенні факту відповідного порушення конкурентного законодавства. Перш за все, йдеться про гіпотетичну ймовірність завдання шкоди іншими факторами, які не стосуються демпінгового імпорту. До таких факторів можна віднести: (1) загальний економічний спад; (2) циклічність відповідної промисловості; (3) імпорт з третіх країн.

Таким чином, у світовій торговельній практиці як на доктринальному, так і на нормативному рівні закріплене поняття демпінгу та його складових елементів, без яких неможливо кваліфікувати нечесну ділову практику як демпінг.

У загальному вигляді наведену концепцію можна поширити і на правопорушення у сфері надання субсидій.

Зауважимо, що ключовим поняттям для конструкції антидемпінгових та антисубсидійних розслідувань $є$ поняття «національний товаровиробник», адже одним із критеріїв застосовності обмежувальних заходів за результатами проведення наведених процедур $є$ належна процесуальна правосуб'єктність заявника (та встановлення факту завдання шкоди галузі національного виробниитва).

Не вдаючись до детального аналізу процедур антидемпінгових та антисубсидійних розслідувань, зазначимо, що поняття національного виробника як суб'єкта відповідних відносин має системоутворююче значення для правопорушення у сфері конкуренції (зокрема, антидемпінгу та антисубсидійних заходів).

Відзначимо, що концепція галузі вітчизняного виробництва або національного товаровиробника випливає із поняття подібного товару [див., наприклад: 6, С. 696]. Наведений підхід концентрується довколо питання суб'єкта, компетентного на подання скарги про конкуренційне порушення та проведення антидемпінгового чи антисубсидиційного розслідування. Крім того, така концепція визначає обсяг відомостей, які необхідно враховувати компетентним 
органам влади, що проводять торговельні розслідування.

Другим елементом наведеної концепції є надання рекомендацій щодо визначення обсягу субсидованого чи демпінгового імпорту, про який стверджується, що він завдає шкоду національному товаровиробнику.

Стаття 4.1 Угоди про застосування статті VI ГАТT передбачає, що термін «галузь вітчизняного виробництва» тлумачиться як такий, що відноситься до вітчизняних виробників аналогічних товарів у цілому або до тих із них, чий сукупний випуск цих товарів становить значну частку загального вітчизняного виробництва цих товарів, за винятком двох випадків, визначених цією ж статтею. Змістовно аналогічне визначення галузі вітчизняного виробництва міститься у статті 16.2 Угоди про субсидії та компенсаційні заходи.

Вбачається, що у статті 4.1 Угоди про застосування статті VI ГАТT співставляються два підходи до визначення галузі національного виробництва. Так, Апеляційний орган СОТ у справі EC-Fasteners (China) (2011) зауважив, що використання терміна «значна частка» у контексті другого підходу компетентними органами, що проводять розслідування, зумовлюе необхідність пошуку відповіді на питання наскільки виробництво товару має бути представлене тими виробниками, що утворюють галузь національного виробництва у випадку, якщо така галузь визначається як менша від виробників аналогічних товарів в цілому. При цьому, однак, статтею 4.1 не встановлюється чітка відсоткова ставка для визначення «значної частки» [19].

Таким чином, поняття галузі вітчизняного виробництва не обов'язково має становити виробництво товарів у цілому, оскільки вітчизняні виробники товару, чиє сукупне виробництво становить значну частку вітчизняного виробництва, також вважаються галуззю національного виробництва.

У контексті викладеного необхідно також зазначити, що у звіті Групи Експертів СОТ у справі Mexico Steel Pipes and Tubes (2007), текст статті 4.1 Угоди про антидемпінг не визначає жодної ієрархії між цими двома підходами. При цьому компетентним органам не дозволяється у ході одного i того самого розслідування використовувати різні підходи [20].

Водночас у згаданій вище справі $E C$ Fasteners (China) (2011) Апеляційним органом також було зазначено, що під «значною часткою» слід розуміти достатньо високий відсоток від загального виробництва товару. Отже, чим нижчим $є$ рівень виробництва, тим більш ретельний аналіз повинні здійснити компетентні органи для того, щоб переконатися, що частка, використана у підрахунку, дійсно відображає виробництво товару в цілому [19].

У контексті визначення галузі національного виробництва слід розрізняти чотири категорії виробників товару: (1) включає виробників товару, які пов'язані з експортерами або імпортерами товару, про який стверджується, що він субсидується або демпінгується. Обсяг виробництва товару вітчизняними виробниками, що підпадають під першу категорію, не враховується при визначенні галузі національного виробництва; (2) складається з виробників, що не підпадають під першу категорію та підтримують скаргу; (3) складається 3 тих виробників, які так само не входять до першої категорії та одночасно не висловлюють жодної позиції щодо скарги; (4) складають виробники, що виступають проти подання скарги та не підпадають під першу категорію.

Отже, галузь національного виробництва слід визначати на основі всіх наведених категорій виробників товарів.

Наведені положення відображені і у національному законодавстві України. Йдеться про Закон України «Про захист національного товаровиробника від демпінгового імпорту» (далі - Закон про антидемпінг) [21] та Закон України «Про захист національного товаровиробника від субсидовоного імпорту» (далі - Закон про субсидований iмnорт) [22], що імплементували відповідні угоди СОТ.

Зокрема, у наведених законах встановлені особливості визначення національного товаровиробника. Так, відповідно до статті 11 Закону про антидемпінг при визначенні 
національного товаровиробника враховуються такі особливості: (1) чи пов'язаний національний виробник з експортером або імпортером товару; (2) чи поділена територія країни на два або більше конкурентоспроможних ринки виробництва подібного товару.

У свою чергу, ч. 6 статті 12 Закону України про антидемпінг містить більш детальне визначення того, яким чином встановлюється процесуальна правосуб'єктність виробників для подання скарги про порушення та проведення розслідування.

Так, за загальним правилом питання щодо достатньої чи недостатньої підтримки вітчизняними виробниками товару скарги про порушення та проведення антидемпінгового чи антисубсидійного розслідування необхідно вирішувати, виходячи із загального виробництва товару на території держави.

Зазначимо, що аналогічний підхід відображено у законодавстві СС [див., наприклад: 23].

При цьому необхідно розрізняти декілька методів встановлення рівня підтримки скарги. За умови, що скаргу підтримує більше 50\% вітчизняних виробників подібного товару, питання щодо процесуальної правосуб'єктності на подання скарги не виникає. Водночас у випадку, якщо частина вітчизняних виробників, що подають скаргу, становить менше $25 \%$ від загального виробництва товару, то група таких виробників не володіє належною процесуальною правосуб'єктністю.

У випадку, якщо рівень підтримки становить між 25\% та $50 \%$ від загального виробництва подібного товару, то слід враховувати виробництво як тих вітчизняних виробників, які підтримують скаргу, так і тих, хто виступає проти їі подання.

Отже, можемо констатувати, що процесуальна правосуб'єктність виникає у випадку, якщо рівень підтримки є більшим за рівень заперечення. Наведений рівень (підтримки чи заперечення) визначається відповідно до відсоткового еквіваленту від загального виробництва товару (за винятком тих виробників товару, які пов'язані з експортерами).
Водночас загальне виробництво можна вимірювати виходячи, з даних товарообігу або кількості реалізованого товару. Перша модель розрахунку (виходячи 3 даних товарообігу) видається більш репрезентативною у разі, якщо йдеться про галузь виробництва, яка має широкий модельний ряд та якщо ціна на відповідні моделі суттєво різниться.

Слід також зазначити, що умовно «нейтральні» виробники (які не висловлюють підтримку та не запереиують проти подання скарги) не враховуються при визначенні рівня підтримки чи заперечення. Водночас виробництво таких виробників береться до уваги з метою розрахунку показників загального виробництва товару.

У випадку з галузями промисловості, що складаються 3 дрібних підприємств, пов'язаних 3 тільки великою кількістю товаровиробників, примітка 12 Угоди про антидемпінг дозволяє визначати рівень підтримки (або висловлення заперечення до скарги) шляхом використання статистично обгрунтованих вибіркових методів.

Слід також зазначити, що для цілей визначення рівня підтримки скарги необхідно враховувати і тих виробників товару, яким субсидований чи демпінговий імпорт не завдає шкоди.

Таким чином, визначення галузі національного виробництва є одним із важливих елементів як до початку ініціювання торгового розслідування, так і в ході встановлення факту наявності шкоди, що може бути підставою для застосування антидемпінгових або компенсаційних заходів.

У контексті викладеного можемо констатувати відсутність чіткої ієрархї понять у сффері торговельного захисту, відсутність їх усталеної інституиійної приналежності. Так, наприклад, надання державної допомоги (субсидії) в окремих РТУ розглядається в межах конструкиї антиконкурентних практик, а не засобів торговельного захисту. Аналогічного висновку можна дійти і щодо демпінгових правовідносин, оскільки, як зазначалося вище, демпінг може кваліфікуватися як нечесну (антиконкурентну) ділову практику. 
Інститут заходів захисту, як вид засобів торговельного захисту, також грунтується на нормах угод права СОТ.

Так, заходи захисту об'єктивовані, наприклад, у статті 3.6 РТУ Туреччина-Сінгапур [2], яка, зокрема, відсилає до статті XIX ГАТТ, Угоди СОТ про захисні заходи [24] та статті 5 Угоди СОТ про сільське господарство [25].

Конкурентні порушення, що можуть бути підставою застосування відповідних заходів, як правило, пов'язуються 3 митними відносинами.

Загальні засади застосування наведених заходів сформульовано у статті XIX ГАТТ («Надзвичайні дії щодо імпорту окремих товарів»), за змістом якої у випадку, якщо в результаті непередбачених обставин та впливу зобов'язань, взятих на себе стороною за цією Угодою, зокрема тарифні поступки, імпорт будь-якого товару на територію цієї сторони збільшується у такій кількості та здійснюється на таких умовах, що це спричиняє чи загрожує спричинити серйозну шкоду вітчизняним виробникам на цій території подібних або безпосередньо конкуруючих товарів, сторона має право, стосовно такого товару, а також тією мірою та протягом часу, які можуть бути необхідними для попередження чи усунення наслідків такої шкоди, цілком або частково призупинити виконання зобов'язання чи скасувати або змінити поступку (пункт 1).

Наведена вище стаття 5 Угоди СОТ про сільське господарство (яка в иілому адаптує положення статmі XIX ГАТТ до особливостей відносин у сфері сільсъкого господарства) пов'язує застосування спеціальних захисних заходів 3 імпортом сільськогосподарського товару, стосовно якого передбачені цією угодою заходи, було перетворено на звичайне мито, і який позначено в його переліку позначкою «SSG» як такий, що 6 предметом поступки (за передбачених цією угодою умов).

Угода СОТ про захисні заходи, у свою чергу, деталізує положення цитованої вище статті ГАТТ; визначає загальні засади відповідного розслідування; встановлює загальні засади визначення наявності серйозної шкоди або іiі загрози; встановлює межі застосування тимчасових захисних заходів; визначає рівень поступок та інші зобов'язання.

Вбачається, що для застосування заходів захисту, як і у випадку з антидемпінговими та антисубсидійними заходами, принциповим питанням є встановлення факту наявності шкоди (або їі відсутності).

Разом 3 тим, можемо констатувати важливу ознаку наведеної форми засобів торговельного захисту, яка виявляється у відсутності нечесної ділової поведінки, що, на нашу думку, впливає на їх правову природу (у контексті їх кваліфікації як правопорушення).

\section{Висновки}

Інститут засобів торговельного захисту має на меті захист національного товаровиробника та опосередкований трьома формами: (1) антидемпінгові заходи; (2) антисубсидійні заходи; (3) заходи загального захисту. Умовою застосування конкретного засобу торговельного захисту є (1) наявність шкоди (або загроза такої шкоди); (2) вчинення антиконкурентних дій; (3) причинно-наслідковий зв'язок між шкодою та відповідними діями. Наведені умови застосування споріднюють заходи торговельного захисту із складом правопорушення. Винятком є засоби захисту, для застосування яких не $є$ необхідним встановлення нечесної поведінки.

Сфера торговельного захисту характеризується відсутністю чіткої ієрархії понять та відсутністю їх усталеної інституційної приналежності. Так, наприклад, надання державної допомоги (субсидії) в окремих РТУ розглядається в межах конструкції антиконкурентних практик, а не засобів торговельного захисту. Аналогічного висновку можна дійти і щодо демпінгових правовідносин, оскільки демпінг може кваліфікуватися як нечесну (антиконкурентну) ділову практику.

\section{Література}

1. J.-F. Bellis; P. Baere. Business guide to trade remedies in the European Community: anti-dumping, countervailing and safeguards legislation, practices and procedures. 


\section{Міжнародне право}

2004. Geneva : International Trade Centre UNCTAD/WTO. 228 p.

2. Turkey - Singapore Free Trade Agreement (TRSFTA). URL: https://www. enterprisesg.gov.sg/-/media/esg/files/nonfinancial-assistance/for-companies/free-tradeagreements/trsfta/turkey-legal-text-trsfta. pdf?la $=$ en.

3. Free Trade Agreement between Hong Kong, China and Georgia. URL: https:// www.tid.gov.hk/english/ita/fta/hkgefta/files/ GEHKFTA_Chapter_7.pdf.

4. Free trade Agreement between the European Union and its Member States, of the one part, and the Republic of Korea, of the other part. URL: https://eur-lex.europa.eu/ legal-content/EN/TXT/PDF/?uri=CELEX:220 $11 \mathrm{~A} 0514(01) \&$ from $=\mathrm{EN}$.

5. Judith Czako, Johann Human and Jorge Miranda. A Handbook on Anti-Dumping Investigations, Cambridge University press 2003.

6. Van den Bossche P., Zdouc W. The Law and Policy of the World Trade Organization / Peter Van den Bossche, Werner Zdouc // Cambridge University Press, 2013.

7. Камініна Т. Г. Демпінг як фінансовий метод торговельної політики. URL: http://www.rusnauka.com/8_NMIW_2008/ Economics/28098.doc.htm.

8. Договір про заснування Європейської Спільноти. Конституційні акти Европейського Союзу. Частина I / Упорядник Г. Друзенко, за загальною редакцією Т. Качки. К.: Видавництво «Юстініан», 2005 р. 512 c.

9. Справа «Корея - заходи, що впливають на торгівлю торговими суднами». URL: https://www.wto.org/english/tratop_e/dispu_e/ cases_e/ds273_e.htm.

10. Угода про субсидії та компенсаційні заходи. URL: https://www.wto.org/english/ docs_e/legal_e/24-scm.pdf.

11. Угода про застосування статті VI ГATT. URL: https://zakon.rada.gov.ua/laws/ show/981 010\#Text.

12. Technical Information on antidumping. URL: https://www.wto.org/english/ tratop_e/adp_e/adp_info_e.htm.

13. Compare GĀTT Ánalytical Index, 223 (Vol 1 1995).
14. Thailand - Anti-Dumping Duties on Angles, Shapes and Sections of Iron or NonAlloy Steel and H Beams from Poland. URL: https://www.wto.org/english/tratop_e/dispu_e/ cases_e/ds122_e.htm.

$1 \overline{5}$. Мироненко В. П. Цивільно-правова відповідальність як вид юридичної відповідальності. URL: http://www.irbisnbuv.gov.ua/cgi-bin/irbis_nbuv/cgiirbis_64. exe? C $21 \mathrm{COM}=2 \&$ I $21 \mathrm{DBN}=\mathrm{UJRN} \& \mathrm{P}$ $21 \mathrm{DBN}=\mathrm{UJRN} \& Z 21$ I D = \&Image_file name $=$ PDF\%2Fjnn_2011_6_3.pdf\&IMAGE_ FILE_DOWNLOAD $=0$.

16. UNCTAD, Dispute settlement. World Trade Organization. 3.6. Anti-Dumping Measures.

17. The WTO Anti-Dumping Agreement: a commentary/ Edwin Vermulst.

18. European Communities - AntiDumping Duties on Imports of Cotton-type Bed Linen from India. URL: http://www.wto. org/english/tratop_e/dispu_e/cases_e/ds141_e. htm.

19. Appelate Body Report, European Communities - Definitive Anti-Dumping Measures on Certain Iron or Steel Fasteners from China. URL: https://www.wto.org/english/ tratop_e/dispu_e/397abr_e.pdf. П. 411.

20. Panel Report, Mexico - Anti-Dumping duties on steel pipes and tubes from Guatemala. URL: https://www.wto.org/english/tratop_e/ dispu_e/331r_e.pdf. П. 7.322.

21. Закон України «Про захист національного товаровиробника від демпінгового імпорту». URL: https://zakon.rada.gov.ua/ laws/show/330-14\#Text.

22. Закон України «Про захист національного товаровиробника від субсидовоного імпорту». URL: [https://zakon.rada.gov. ua/laws/show/331-14\# Text.

23. Council Regulation (EC)No. 1225/2009 as of 30 November 2009. URL: http://trade.ec.europa.eu/doclib/docs/2010/ april/tradoc_146035.pdf.

24. Угода СОТ про захисні заходи. URL: https://www.wto.org/english/docs_e/legal_e/25safeg_e.htm.

25. Угода СОТ про сільське господарство. URL: https://zakon.rada.gov.ua/laws/ show/981_005\#Text. 


\section{АНОТАЦІЯ}

Стаття присвячена регулюванню засобів торговельного захисту на рівні регіональних торговельних угод. Автор доходить висновку, шо спільними рисами засобів торговельного захисту можна вважати загальні засади їх процедурної реалізаиій (йдеться передусім про необхідність проведення відповідного розслідування як підстави для застосування кожної з наведених форм засобів торговельного захисту). Констатовано, що заходи торговельного захисту мають низку спільних рис із складом правопорушення як підставою юридичної відповідальності (як інститутом захисту прав, свобод та інтересів суб'єктів права у начіональній правовій доктрині). Йдеться про необхідність встановлення таких юридично значимих обставин як здійснення дій, що забороняються (засуджуються) (демпінг; заборонене субсидування) наявність шкоди; причиннонаслідковий зв'язок між шкодою та наслідками, щзо спричинили відповідні дї (демпінг або заборонене субсидування). У статті детально висвітлені основні засади концепиіі національного товаровиробника як суб'єкта, на захист якого спрямовані засоби торговельного захисту як інститут конкурентного права.

Ключові слова: засоби торговельного захисту; захист конкуренціӥ; регіональні торговельні угоди; антидемпінг; субсидї; заходи захисту.

\section{Anna L. Gladshtein, \\ Lecturer of Private international law chair of Institute of International Relations \\ of Taras Shevchenko National University of \\ Kyiv \\ TRADE REMEDIES AS COMPETITION DEVELOPMENT INSTRUMENTS UNDER REGIONAL TRADE AGREEMENTS}

The Paper is devoted to trade remedies regulations under the regional trade agreements. The Author stated that the main goal of trade remedies as a legal institution is protection of national market from foreign manufacturers. Despite of recognizing of trade remedies as a legal institution of competition law under current RTAs, the Author concludes that named institution is inherited with cross-link for other allied institutions, which results in absence of unified fine-tune mechanism of understanding of fundamental principles named institution (e.g. anticompetitive practices). Indicated convergence is a result of pragmatic approach for legitimation of noted legal institution under the RTAs. Trade remedies traditionally include antidumping, anti-subsidy and competition safeguards. The Author claims that named trade remedies have common features, which are main principles of its procedural realization (particularly, it is intended to necessity for relevant investigation as a ground for use of each named trade remedy). It is noted, that trade remedies share some characteristics with corpus delicti (as an institution of defense of rights under the national legal doctrine). It is referred to need for establishment of facts of legal significance, in particular prohibited (condemned) actions (dumping, prohibited subsidy), harm (loss) existence, causal connection between harm (loss) and consequences. The Author also determines differences in legal nature of competition safeguards in comparison with antidumping and anti-subsidy. It is nuanced main concepts of national manufacturer as participant of a market, whose protection is a main goal of trade remedies as institution of competition law.

Key words: trade remedies, competition protection, RTAs, antidumping, subsidy, competition safeguards. 